\title{
Apologeticism in Chinese Nestorian Documents from the Tang Dynasty: Notes on Some Early Traces of Aristotelianism in China
}

\author{
Jan VRHOVSKI *
}

\begin{abstract}
Founded on the fact of otherwise deep connections of Nestorianism to the Aristotelian philosophy, this article hopes to shed some light on the possibility of a concurrent transmission of Aristotelianism (with Nestorianism) to China. This writing proposes that the transmission already took place during the early period of the presence of this form of Christianity in China. Taking a brief look into some representative writings about the Nestorian doctrine written in the Chinese language, this writing hopes to establish some modest, though still relevant, connections between Aristotelian concepts on the one hand, and some fragments of the mentioned Chinese writings on the other.
\end{abstract}

Keywords: Nestorianism in China, Aristotelian philosophy, apologeticism, Tang dynasty

\section{Izvleček}

Osnovan na dejstvu globoke povezanosti med nestorjanstvom in aristotelsko filozofijo, želi ta članek razjasniti okoliščine verjetnosti skladnega prenosa nestorjanstva in Aristotelove teorije na Kitajsko. Le ta naj bi se, kot predlaga ta članek, pričel vršiti že v najzgodnejšem obdobju prisotnosti te vrste Krščanstva na Kitajskem. Skozi kratek vpogled v nekatera značilna nestorjanska besedila, napisana $\mathrm{v}$ kitajskem jeziku, želi pričujoč sestavek utemeljiti nekatere, sicer previdno zastavljene, povezave med aristoteljanskimi koncepti na eni strani ter nekaterimi izseki iz omenjenih nestorjanskih besedil na drugi.

Ključne besede: Nestorijanstvo na Kitajskem, aristotelska filozofija, apologetika, dinastija Tang.

\footnotetext{
* Jan VRHOVSKI, PhD Candidate, Asian and African Studies, Faculty of Arts, University of Ljubljana, Ljubljana vvei.yang@gmail.com
} 


\section{Introduction}

Although we are clearly engaging ourselves with a fairly distant matter, obscured by the veils of oblivion and disappearing behind the scarcity of surviving documents, our glimpse will hopefully shed some light on a different aspect of the Nestorian teachings in China, and the possible influence it could have had on Chinese thought of the period. The main problems concerning the historiography of the Nestorian movement in China may only have been of ideological nature, stemming mainly from the fact that, regarding Chinese history, various authors engaged in the studies of all forms of thought commonly designated as Christian. They have either been Christian missionaries, or early geographical and ethnological explorers in later periods. That leaves us with only few, though quite thorough contributions by the Japanese philologists. In the same way, the Chinese interest in the special character of cultural encounters between Western thought and China was lacking intensity due to certain inclinations, which were direct or indirect result of recent or quite recent history. Although a window of acceptance and reintegration of Western thought and culture had been opened anew since the beginning of the Jesuit era, the same fact contributed to the partial dissonance between the true meaning of Nestorian legacy in China, and broader East Asia, and the cardinal importance for the Jesuits to represent the presence of Nestorianism in China as an evidence, or a utility legitimising their missionary presence among the Chinese people, uttering a reminding slogan, that "Christ has been known to the Chinese people since ages." The legitimisation of the roots of Christianity as a sole doctrinal body hence overshadowed the necessity of a thorough inquiry into the matter of doctrinal influence and possible congruence between two or many different cultures of Tang dynasty China.

Following the thread of Nestorianism in China back in time, we arrive at the moment in history, when the cultural borders of the Chinese Empire encountered an extraordinary openness. Although an even earlier presence of Nestorianism in China cannot be excluded - we have all reasons to believe that first contacts have been as early as in the sixth century AD - the first major encounter between the cultures on Chinese grounds and the following official recognition of Nestorianism can be set to the year 635, when bishop Alopen arrived at Xi'an, followed by a group of emissaries. Even though such official encounters, along with major historical events concerning the contacts between Chinese and members of the Nestorian Church have been fairly documented, generally speaking, we are left mainly with documents of another kind, namely those with a 
purely doctrinal character. As our concern here is solely with the question of doctrine, we must beforehand establish the level of plausibility of existence or relevance of the doctrinal history of Nestorian Aristotelianism in China.

Our short stroll through the archives of early Nestorianism in China is not as lonely as it may seem. The originality of this intriguing topic has been lost in some earlier works on Nestorianism in China, and remained only in a form of showy figures of possible connections between expounding thoughts of Christian doctrine and underlying Aristotelianism. One such early case of sparkling intuition, followed by a somehow inadequate conundrum of analogy, can be found in Feng Chengjun's $(1931,70)$ writings on the Inscription of the Nestorianism Spreading in China. All the subsequent inquiries into the question of Aristotelianism in China only briefly mention the possibility, or even start a historical investigation in a less distant period, which is almost unequivocally the beginning stage of Catholic missionary activities in East Asia. There is no special need for us to bring up the resounding critiques of an orientalistic attitude, as we can most safely confine our critical standpoint to the principles of uncertainty; it is most certainly safer to discuss questions for which we have a better historical account, but a certain degree of probability can after all be established even for our case.

The question of a deep-rooted inner connection between Nestorianism and Aristotelian thought is, especially for a historian of medieval philosophy or theology, not a mystery at all. We can read in many sources about their early translations of various Greek philosophers' works, especially those of Aristotle:

[...] between the fifth and seventh centuries translations were made from Greek into Syriac, particularly translations of medical works and, even more, of logical works. The first books of Aristotle's Organon were, then, not merely translated but received a number of commentaries. (Marenbon 2004, 30)

Those translations made by Nestorian and Jacobite scholars are a historical gateway to reintroduction or reintegration of Aristotelian philosophies into leading Mediterranean philosophical and theological systems of the time. The development of Islamic philosophy, which followed the dawn of Christianity in Mediterranean cultures, most probably owns a considerable degree of its deep insight into Greek philosophy to those early schools of thought. They comprised first considerable translations of Aristotle into other important languages of any literary value, such as Syriac (a literary form if Aramaic). One of the leading 
schools in activities described above were absolutely the Nestorians, who's most common "ideological" designation was coined in accordance with their close doctrinal affiliation with Aristotelianism.

With the spread of this form of Monophysite Christianity, doctrinally formed on the logical, "metaphysical," and physical background of Aristotle's theory, the importance, or onto-moral aspect of its (apologetic) theoretical applications spread accordingly. In a certain way we should not be too sceptical towards the possibility of the concurrently plausible notion of Aristotelian theory in Tang dynasty China. Although a certain degree of plausibility can be expected, the importance or actuality of its existence should not be taken with any seriousness exceeding the moderately set limitations of scientific.

We will start our relatively brief overview of some apologetic and doctrinal peculiarities of Nestorian documents in China with a modest presupposition, claiming that in the $7^{\text {th }}$ and $8^{\text {th }}$ century $\mathrm{AD}$ the "entanglement" between the underlying content of Nestorianism and doctrinal application of a segment of Aristotelianism was substantial enough to lead to a considerable formalization within the framework of the textual monuments of the Tang dynasty China. With this certain predisposition, all cases of possible analogies to the content of Aristotle's philosophy can be relevantly interpreted as an adaptation of traditional Chinese thought, which, as we will hopefully be able to show, was also present in Chinese Nestorian texts. Although we can avoid interpretational ambiguities by assuming that the Nestorian reasoning was already entwined with Aristotelian philosophy by the period of Chinese missionary activity, it is also reasonable enough to allow an interpretation which explains the figures, ideas etc. used in Chinese Nestorian writings as doctrinal figures, only an order of useful analogies to the Chinese culture, applied as an utility for apologeticism and proselitysm.

\section{Cases of Consistency between Aristotelian Thought and Chinese Cosmologies}

Systemic discrepancies between cultural substrate and the intruding doctrine are not necessarily present in entirety, even in encounters between cultures with cradles separated in distance such as the Mediterranean to China. In our case with some Nestorian inscriptions and writings we can definitely find some ambiguities which have possibly been perceived as doctrinal "blind spots" for interrelating 
apologetics. We can find one such example in the famous stele raised as a monument to propagation of Nestorianism in China from 781 AD. Saeki $(1951,53)$ translated the title on the monument with following words: A Monument commemorating the Propagation of the Ta-ch'in Luminous Religion in the Middle Kingdom. The key cosmological elements in the introductory eulogy about the one god and creator of the universe can be traced back to either Aristotle, or early Chinese Cosmological theories. Let us first quote the text in question:

[...] there is One who is true and firm, who, being Uncreated, is the Origin of the Origins; who is ever Incomprehensible and Invisible, yet ever mysteriously existing to the last of the lasts; who, holding the Secret Source of Origin, created all things, and who, surpassing all the Holy ones, is the only unoriginated Lord of the Universe, [...] (Saeki 1951, 53)

This text is Saeki's translation of original Chinese lines:

常然眞寂 先先而無元

䆩然靈虚 後後而妙有

總玄摳而造化 妙衆聖以元尊者

(Taishō 94b, 1289)

Although this translation is not accurate enough for a linguistic study of the original, we will have to rely on the basic interpretational premises which can be derived by observing the proposed translation and the original text at the same time. As it can be seen from the original, the terminology used as a doctrinal vessel of expression is mainly of Daoist and Buddhist origin which is somehow conveniently transforming the given contents into a seeming analogy of their own doctrine. Examples like this are our theoretical "blind spots," obscuring a possible connection to the underlying identity with Aristotelian theory. Many parallels with the Aristotelian philosophy can be given to match the contents.

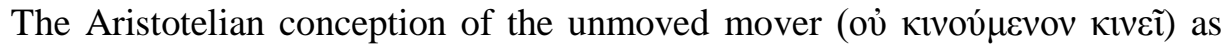
the first principle or origin of origins ${ }^{1}$ is being equalized with God in many different places in Aristotle's creed, as is the origin of origins designated as being without further origins and having no creation of its own "being." God described in the writing of the Nestorian stele already (from the $3^{\text {rd }}$ century AD) holds the name, or a secondary definition of being the triune God.

\footnotetext{
${ }^{1}$ With these two or more expressions we normally refer to the Old-Greek substantive $\dot{\alpha} \rho \chi \dot{\eta}$.

${ }^{2}$ This can be found in writings such as: Physics, Metaphysics (Book no. II), On the Heavens, On the Universe etc.
} 
The first part is followed by a cosmological description:

Dividing the Cross, He determined the four cardinal points. Setting in motion the primordial spirit, He produced the two principles of Nature. The dark void was changed, and Heaven and Earth appeared. The sun and moon revolved, and day and night began. Having designed and fashioned all things, He then created the first man and bestowed on him the excellent disposition, superior to all others, and gave him to have the dominion over the Ocean of created things. ${ }^{3}$ (Saeki 1951, 53)

A proper conundrum of excerpts woven by works attributed to Aristotle can be given below. We hope to provide a counterexample to the two quotations as follows:

It is more worthy of his [God's] dignity and more befitting that he should be enthroned in the highest region, and that his power, extending through the whole universe, should move the sun and the moon and make the whole heaven revolve and be the cause of permanence to all that is on this earth. [...] So is it with the universe; by a single revolution of the whole within the bounds of day and night, the different orbits of all heavenly bodies are produced, $[\ldots]$ For the moon accomplishes her circuit in a month, waxing and waning and disappearing; the sun and the heavenly bodies whose course is of equal length, [...], perform their revolution in a year. For at the signal given from on high by him who may well be called their chorus-leer, the stars and the whole universe always move, and the sun that illuminates all things travels forth on it double course, whereby it both divides day and night by its rising and setting, and also brings the four seasons of the year. And in their own due season the rain, the winds, and the dews, and all the other phenomena which occur in the region which surrounds the Earth, are produced by the first, primeval cause. [...] When, therefore, the ruler and parent of all, invisible save to the power of reason, gives the word to all nature [...], the whole revolves unceasingly $[\ldots]$, sometimes unseen and sometimes appearing, revealing and again hiding diverse manners of things, form one and the same cause. [...] For all that happens in the air, on the earth, and in the water, may truly be said to be the work of God, who possesses the universe; from whom, in the words of Empedocles:

Whatsoever hath been and is now and shall be hereafter,

All alike hath is birth-men, women, trees of the forest,

Beasts of the field and fowls of the air and fish in the water.

(Barnes et al. 1984, 636-37)

${ }^{3}$ 十字以定四方。鼓元風而生二氣。暗空易而天地開。日月運而書夜作。匠成萬物然立初人。 別賜良和令鎭化海。(Taishō 94b, 1289) 
Although the text quoted (entitled On the Universe) is attributed to the creed of the so called Pseudo-Aristotle, it still bears the same relevance for our inquiry, as it doubtlessly forms a part of the same doctrinal system, namely the creed of Aristotelianism. What is also important about the Aristotelian cosmology, yet not used in the given excerpt, is the importance of the four principles - not to be confused with the prime principle - and the prevalence of the quadric-polar cosmology, some single aspects of logics and morality that follow from the holistic quadric-polarity of the continuing universe.

In the chapter IV of Physics we can read a discussion about the nature of the notion of space in the following few sentences:

Further, the locomotions of the elementary natural bodies - namely, fire, earth, and the like - show not only that place is something, but also that it exerts a certain influence. Each is carried to its own place, if it is not hindered, the one up, the other down. Now these are regions or kinds of place - up and down and the rest of the six directions. (Barnes et al. 1984, 50)

Here we are told about the coherence or harmony between the four principles which form the phenomena of the World, each following its special movement of Nature. When it comes to the so called regions of place we are again told that there are six constituent directions; moving up and down to the planar four, which are mentioned in the Chinese text by implementing at the same time the most representative symbol of the Christianity, the cross. But taking a cross is also taking into account some mathematical laws, which in the Greek philosophy were as we know, also implied to as the systemic properties of the archaic or the first principle of the Universe. The main interpretational problem here is the ambiguity of different perspectives which Aristotle takes in his descriptions of the Universe. Taking into account, for example, the spherical structure of the universe as a moving or revolving whole, only two poles are mentioned. These two are relative to the movement itself, and are as such perceived as poles in a mono-centric world-model, meaning that they are static, unmovable "dots" which, when connected, divide the "globe" in two halves. But as the "four cardinal directions" (si fang 四方) are necessary to be viewed upon as a traditional Chinese concept, stemming from the earliest political or religious cosmologies known to have existed in China, we are obliged to neglect the possibility of a presence of purely Aristotelian thought, and to perceive the use of the phrase or concept as an apologetic necessity, used in order to integrate the doctrine to a more radical level of Chinese culture. The sifang concept, as already mentioned before, is thought to 
have its origin in Shang dynasty (ca. 1700-1045 BC), where it formed the central cosmological concept on a par with the notion of centre as the loci sine qua non. The cosmological entirety, "fully manifests centrality through symmetry oppositions." (Wang 2000, 23) Various interpretations and further integrations of these cosmological notions into a broader image of a conception of the World as a whole include suggestions such as "the concept of the five $D i$ 帝" (Wang 2000, 23). Furthermore, the cosmological image is thought to be identical with a " $y a$ 亞shaped notion of the earth" (Wang 2000, 23).

We can summarize the explications of a cosmological level of the sifang concept with the following quote from Wang Aihe's book on early Chinese cosmology and politics:

[...], Sifang as four directions and a classification structure included alien people living on the periphery and the gods of Sifang, who had spiritual influence over the actions of alien polities in the same way that they influenced rain and wind coming from the four directions. Expressed in these interchangeable terms, Sifang as a cosmological structure classified all forces of the universe, including spirits, beings, and natural powers [...] For the Shang people, all these forces were commanded by the high God $D i$ 帝, who used them to determine the well-being of the Shang. (Wang 2000, 29)

For us the importance lies in the connection between the notion of the World as a cosmological or phenomenological whole and the corresponding notion of a supreme divine being, which bears some equal morphological features as the concept of the Christian, Nestorian or Aristotelian God. This connection would offer a plausible explanation of the apologetic nature of its usage in the Chinese text about Nestorian doctrine. The supremacy of the Nestorian God would in a way surpass all the other possible deities confined to locality of a single fang, for their God is the creator of every single one of them.

As regards the two principles of nature mentioned in the text, they can again be followed back to the traditional Chinese cosmological systems or philosophies, with an utter obviousness - yin 阴 and yang 阳 etc. Subsequently, the connection with Aristotelian theory can be looked upon as being natural in itself; the two columns of cognates, such as darkness versus light, man versus woman etc. are extended through various cases in the Aristotelian theory, forming a universal dialectical opposition at a level surpassing matter as such, and its modifications and states at a certain level (Barnes et al. 1984, 1559). 
Again, the consistency of the second quote from the Nestorian stele with the Aristotelian theory can be constituted in the case of the notion of the God as the supreme or primal mover, who set the existence which is always in movement. The same can be also said about setting the primordial spirit/soul ( $\pi v \varepsilon v \dot{\mu} \alpha=f e n g$ 風= “wind") into existence, about which we can read in Aristotle's book On Soul. Aristotelian implications of the spiritualistic aspect of its cosmology on the difference of man's constitution in regard to other beings can be further traced to the Christian doctrine itself, so that in turn we can regard the content of the inscription mentioning this conception as an already intertwined doctrinal entity, in some way vital to the man as a being, philosophising about the true nature of the reality beyond mere sensation.

Reaching the end of the second example of Saeki's translation of the Chinese text from the Nestorian stele, we must again emphasise that the translations themselves could have been given more attention, for they can most certainly be brought to a level complying the intended meaning in Chinese. But regrettably, and for the sake of sparing the reader with additional excursions, we wowed rely partly on the already existent translations and the Chinese version at the same time.

The continuing red string of this narrative takes the visitor of the site commemorating Nestorianism towards an explication of the Biblical plot of man's defilement, caused by Satan's deceiving employment of evil devices on him, in order that man's originally pure nature would undergo a qualitative spiritual bifurcation. This is then followed by the era of mankind's hopeless confusion, blindness and consequent damnation. This kind of generalisation of epistemological foundations for phenomenology can be seen in some aspects of Chinese Buddhism. Naturally, after the downfall of the mankind, we then reach the point in Biblical history where the Messiah causes this order to reverse, and the mankind to regain the "clarity of vision." Messiah's life and works are definitely found wrapped in the Buddhist imagery and symbols, for which the sole reason is obvious enough; the Buddhist imagery is concentrated on the person, lives etc. of Buddha and his Bodhisattvas, and secondary also on the notion of illumination and enlightenment. 


\section{Sanctity and Buddhism: Apologetics and Dogma in Dissonance with the Traditional Chinese Thought}

As regards the conceptual arsenal used by Nestorian linguistic and systemic translations of the fundamental dogma, we must agree on the fact that the majority or the greatest part of terminology is adapted from and derive from the Buddhist doctrine. ${ }^{4}$ The main reason for such an ideological propensity lies most probably in its compatibility with the secondary metaphysical conceptions and systems of some forms of Chinese religious Buddhism (as are the Jingtu 净土 and Tiantai 天 台 schools of Buddhist thought). At the same time we must not forget the political importance of Buddhism in the introduction period of Nestorianism to China. At the level of the cosmological grounds of Nestorianism the dissonance between traditional Chinese systems is of a most clear kind. The moral doctrine of Confucianism is on the other hand totally acceptable for the moral implications of the Judeo-Christian onto-moral system. The compatibility between Nestorianism and Confucianism can be further seen within the frame of its doctrine which regards the hierarchical social order, which later on, if harmonized, leads to the manifestation of the "good" in the kingdom of men. This consistency between Aristotle's Nicomachean ethics, Politics etc. (as well as some features of Platonist ideas about statesmanship) and Nestorianism on the other hand is most evident in the last part of the text of the so called Jesus Messiah Sutra, where the word is about the Sacred superior, the prevalence of manifestation of the good, causality of morals, and so on (Saeki 1951, 133). The introduction of the above-mentioned "Christian" moral system is not intelligible at all; likewise is the connection of its roots to the Greek philosophy which is a matter of common knowledge. Therefore, we can consider any further reference to this aspect as unsubstantial for our investigation.

Although the ending lines of Jesus Messiah Sutra are almost entirely devoted to questions, i.e. topics mentioned above, the text begins by introducing the concept of the One God, his position in heaven, and continues to answer the question of his appearance. For instance:

No human being, however, has ever seen the Lord of Heaven abiding with people. [...] And this is because the Lord of Heaven is like the wind in His countenance. And who could possibly see the wind? The Lord of Heaven incessantly going around all over the world, is constantly present everywhere.

\footnotetext{
${ }^{4}$ And vice versa; see: Seung 1996, 192 etc.
} 
On account of this, every man existing in this world only obtains life and continues his existence by the strength of the Lord of Heaven. [...] All the Buddhas "flow and flux" (i.e., wander here and there) by virtue of this very wind, while in this world, there is no place where the wind does not reach. (Saeki 1951, 125-26)

Here we find ourselves in an unfortunate position of not having the original Chinese version at our disposal, and have therefore to rely only on the translation given by Saeki and are hence confined to a semi-objective insight into the basic text material. Otherwise, if the given translation is consistent enough, we can still deduce some major features about the content of the regarding document. The key momentum we can rely upon in the task of making some systemic connections to the Aristotelian creed is the equalising force, which operates between the recurring notion of "wind" and the synonymous concept of "soul." Using the next synonymous term in the line, namely "spirit," would be erroneous in a way, since the notion of spirit, used in Aristotelian sense, refers to a concept of rather a substantial nature. On the other hand, as we can read in Aristotle's On the Soul, the concept of soul forms a more complicated sphere of definitions and analogies, which are in a seeming accordance with the statement that every being is existent due to its presence at the first place. Such is also Aristotle's own conception of soul:

[...] the soul must be an account and essence, not matter or a subject. For, as we said, the word substance has three meanings - form, matter, and the complex of both - and of these matter is potentiality from actuality. [...] the body cannot be the actuality of the soul; it is the soul which is the actuality of a certain kind of body. [...] It is the source of movement, it is the end, it is the essence of the whole living body. [...] It manifests that the soul is also the final cause. (Barnes et al. 1984, 657-59)

Further, we can also read:

The soul is also the cause of the living body as the original source of local movement. The power of locomotion is not found, however, in all living things. But change of quality and change of quantity are also due to the soul. Sensation is held to be a qualitative alteration, and nothing except what has soul in it is capable of sensation. The same holds of growth and decay; nothing grows or decays naturally except what feeds itself, and nothing feeds itself except what has a share of life in it. (Barnes et al. 1984, 660)

The summarizing sentences in the third book of the treatise On the soul rephrase the soul as the essence of all existent things: 
Let us now summarize our results about soul, and repeat that the soul is in a way all existing things; for existing things are either sensible or thinkable, and knowledge is in a way what is knowable, and sensation is in a way what is sensible: in what way we must inquire. (431b20-431b23) (Barnes et al. 1984, 686)

The omnipresence of the soul, which is in a way secondary to the God-the question is answered incompletely because of the designation Aristotle makes about the mind (the agent intellect) as being immortal and immaterial-is not the movement the secondary "spirits" are caught within; they are caught in the movement ordered, or caused by the supreme mover (407b1-15), due to their phenomenological condition. If we, in due course of this discussion, do choose to accept the seeming equality or representation of the concept of "soul" with the agent notion of "wind," we can reinterpret the description in the text in accordance with Aristotle. Arriving at a conclusion in this manner may not guarantee any relevance for the possibility. Another (a more thorough) approach would have to include a comparative analysis of the pragmatics of Chinese terminology used in the entire Nestorian corpus. Anyway, the fact which can be derived from reading the Sutra is, that the "wind" is described as a divine agent, which still transcends from the supreme being itself by the sole fact that "the Person (of the Lord of Heaven) is in brightness, joyous and peaceful, and dwells in Heaven and comfort" (Saeki 1951, 126). The given description can be seen as a vulgarised (in a moderate sense) perception of morphology of the Supreme Being and its abode, the supreme level of existence.

The God's omnipresence can also be viewed upon from a more systemic perspective of Aristotle's conception of movement:

The energeia which is the Prime Mover is not only actuality without any residual potency, but also an activity of precisely the kind distinguished from kinesis in Metaphysics ix.6. The difference, of course, is that it is an activity subsistent in its own right; that is what is added by the fusion with the concept of actuality. (Bradshaw 2004, 24)

Another striking resemblance with Aristotle's theories can be found in the same text, where the apologetic takes the soul into consideration from a distinct perspective, like in the next few sentences:

All the living beings have each a fixed span of life because of this wind (i.e., breath) in them, When life is no longer, and one is about to die, then is the time when this wind (i.e., breath) leaves one's body. Thought and mind of all 
human beings are not the wind itself. They are things that owe their existence to the wind. (Saeki 1951, 128)

Whilst keeping in mind the brief account of the Aristotle's conception of soul which we have already given (though the main parts of the definition and further structural features have been left out), and which can be related to the first part of the above citation, the importance is laid on the last two sentences which reflect the exceptional character of mind, thought and memory as described by Aristotle. Relevant for this matter is also Aristotle's treatise titled On Memory (449b4453b11). Intellect, i.e. mind, is a part of the soul, which is not coherent with the soul as essence itself; consequently, are the images used by it (thought) in the same way in a relation surpassing the features of a persisting presence of the soul as essence. $^{5}$

The difference between the materiality of atoms and the entity of a human being is further emphasised and formulated by the following statement in the Sutra:

Staying on this earth all living beings will have their "flow and flux" respectively, whilst all the atoms even have to undergo transformation and vicissitude. (Saeki 1951, 128)

\section{Catching Aristotle's Tail: A Discourse on Monotheism}

The last part of our investigation, where we will try to delve a bit deeper into the obscurity of Aristotelian cosmology utilised to confront the otherness of Chinese cultural perception, concerns itself with a Nestorian document bearing some curious resemblances, if not even identity, with some Aristotelian texts.

The discourse begins with a quite usual form of introducing the One God, creator of earth and heaven etc.:

All things manifest the one God. All things without exception are, therefore, no other than the one God. Everything that is made, without exception, is like the manifestation thereof. [...] This will account for heaven being made to remain at ease and earth being made safe until now without change. There is neither pillar nor prop to support the Heaven. Unless the one God does so, how can heaven remain so long without falling from above? This is due to no

\footnotetext{
${ }^{5}$ This thought needs further elaborations, as well as a better referential grid established to verify its relevance in Aristotelian thought, but these will be avoided at the moment due to a definite shortage of space and time.
} 
other than the mysterious and wonderful power of the one God. (Saeki 1951, 161)

Different places in the Aristotelian canon reflect some ideal consonances with fragmentised propositions in the upper text. For example, an excerpt from PseudoAristotle's book On the Universe (391b9-392a4):

The Universe then is a system made up of heaven and earth and the natural things which are contained in them. But the word is also used in another sense of the ordering and arrangement of all things, preserved by and through God. Of this Universe the centre, which is immovable and fixed, is occupied by the lifebearing earth, the home and the mother of diverse creatures. The upper portion of the Universe, a whole with a fixed upper limit everywhere, the home of the gods, is called Heaven. Heaven is full of divine bodies, which we usually call stars, and moves with an eternal motion, and in one circular orbit revolves in stately measure with all the heavenly bodies unceasingly forever. (Barnes et al. 1984, 626)

As it is evident from the upper text, the notion of the fixation of the heaven and earth refers to their position within the constitution of the universe. Whilst all other descriptions seem to be in a relative agreement, or not being in a thorough disagreement, with some parts or aspects of Aristotle's theory, is the traditional Chinese cosmology absolutely at the odds with it by setting up a gravitational and mono-substantial theory of the universe, as a system consisting of earth at the bottom, and heaven as a body (though in movement) having a certain weight which must be held at the distance using some cosmic pillars. Explicated with a sense of a quotidian way of eloquence, the Nestorian text in turn presents up with a statement; it is due to the 'power' of god that the universe persists in such order.

A further set of explications about the principle of the good, to which we tend to strive in our lives in order to achieve blessedness of a kind, can be found in Aristotle's Nicomachean Ethics (1178b23-1862) and Eudemian Ethics (1248b71978), accordingly:

Therefore the activity of God, which surpasses all others in blessedness, must be contemplative; and of human activities, therefore, that which is most akin to this must be most of the nature of happiness. (Barnes et al. 1984, 1862)

And:

The answer is clear: as in the universe, so in the soul, it is god. For in a sense the divine element in us moves everything. The starting-point of reasoning is not reasoning, but something greater. What, then, could be greater even than 
knowledge and intellect but god? For excellence is an instrument of the intellect. (Barnes et al. 1984, 1979)

The Nestorian Sutra places mankind in the position betwixt two dimensions of existence, describing it as inherently unfulfilled due to its current mode of existence. The blessedness on the other hand has its ipso facto existence in the man's complex soul and the absolute state of the unmoving mover. Following from that is the premise, that the only way towards enlightenment must necessary lead from and through the innate 'mind' to the state of the god in heaven. Hence we can read in the sentences which follow the cosmological part:

Man at present is considered to be at a place of rest between heaven and earth. Man, however, has no place of rest. On account of this, this (world) may be said to be a place of restlessness. To place oneself securely (in this world) may be likened to one trying to place oneself securely upon the water. (Saeki 1951, 162)

After giving again a brief account of steadfastness of the universe, the Sutra repeats the paradigm of the presence of the divine force which holds together the universe. In the opposite case, "if the divine power were not working, heaven and earth" would most definitely "fall to pieces" (Saeki 1951, 163).

Following the repeating pattern of contents appearing in a chain of cosmological propositions within the Sutra, we arrive to the next point which bears some relevance for our brief inquiry:

Though $\mathrm{He}$ himself is invisible, yet there have been indeed, two manifestations (of the One Godhead). For instance, these may be likened to one's right and left hands or legs. But there are no such distinctions of before and after or of upper or lower (between them). They are so alike that one can not be distinguished from the other. Likewise, the one Godhead begot the other one (person of the Godhead) out of one and the same substance and form. [...] Now this God entirely takes (the form of) one single being, and there can not be, indeed, any second or a third (Being). (Saeki 1951, 164)

Supposing that this given account of the so called two manifestations (er jian二见) refers to the two aspects which have been designated in Aristotelian philosophy as opposites or contraries, and of which there had beem given no specific theological account, the analogy with hands can be regarded as a paraphrase, aiming at unipolarity of the underlying substance of the opposites, or the prime matter itself (Anagnostopoulos et al. 2009, 179). Hence the identity of the underlying matter in the analogy of the hands evidently stresses its relation to the existence of an 
opposition which, taken through a perspective of metamorphosis, exist as contradictories or contraries. In next few sentences we are informed only about the material nature of our perspective, which, thus viewed, must be seen as a unity in the first place. Although Aristotle, like his predecessors, turns for the view that all change in the universe 'takes place' between contraries, a secondary opsis through the gridlines of his reasoning, namely that "[...] all things are one, and not only opposites" (1007a1-1007a8), is also discussed in Metaphysics and especially Physics I. Additionally, the question and definitions of opposites are also further discussed in Categories (11b15-) and Metaphysics (1018a20-1018a24).

In the following verses we can read about the world of tangibility and nontangibility, which transcends the former or exists in a non-parallel parallel. What is meant by the notion of tangibility is the continuum coherent with the substantial world, and the given example sketches the difference between the continuum of time and space and the non-continuum, using an analogy with a point and a line. We hope that no further reference to geometrical fundamentals of Greek philosophy is needed to clarify our point here.

Before the Discourse on Monotheism sets its concluding remarks, a brief description of man's constitution is given (spirit, soul and body), arguing the way and order in which they coexist, or that they cause one another to move or function. The entire description is summarised by a mosaic of propositions about soul and being, which have already been mentioned above in our brief inquiry.

We have tried to encompass some obscure images in a relatively relevant ostension of the Aristotelian pillars of Chinese Nestorian creed. At the very end of the discourse about oneness of god is the most Aristotelian of all thoughts, namely:

But if anyone should inquire how many things and how many men are created (by God) then answer: All things in universe may be tracked back to four elements. (Saeki 1951, 168)

\section{Conclusory Remarks}

Although we have evidently set out on a ungrateful quest for some factual consistencies which would be able to create some relatively substantial evidence about the possibility and formations of Aristotelianism in China in its earliest phases, a small step has been taken towards thedistant point of clarity. For the far- 
reaching and thoroughly entangled conundrum of ambiguity, cultural consonance and acquisition of cultural concepts have also been described along with the modest indications that the sought-for fact may exist. Hence we may establish, with all due awareness, that the probability of prevalence of Aristotelian thought in apologetic parts of the doctrine within Chinese Nestorian texts is more than indicating, but it (Aristotelianism) most clearly functions with a coherently applied theological, iconographical, and cosmological basis taken from prevailing religious aspects of Chinese Buddhism or Daoism, and in some places even Confucianism. Naturally, the linguistic and cultural environment must be given the position of the agent of doctrine, but nevertheless, it is regarded as a substratum on which the grounds for Nestorian dogma can be set, because the one god holds no place for another one (if he would, the universe would fall apart). From all aspects and axioms of Aristotelianism only those of cosmological and ontological, along with the very important psychological, value can be seen as used in an absolute majority of cases, mainly in order to fill the gaps which exist in "bible's" conception of the universe.

Most important for us to stress in this conclusory remarks would be perhaps the self-evident and otherwise obvious fact that something which we perceive as the fundamentals of western thought and humanism has been in an almost permanent, though opaque, contact with China and its cultures since some most distant periods in history we have almost lost all account of, even on "our," Western side. Keeping this in mind, the cleavages of the negative perception of compatibility or incompatibility or even fundamental otherness which ought to dwell amidst our worlds, can be taken cum grano salis, for the one, and a spirit of congruence and mutual learning may be given a possibility to gain some more intensity, for the other.

\section{References}

Abramovski, Luise and Goodman, Alan. 1972. A Nestorian Collection of Christological Texts - Volume II: Introduction, Translation and Indexes. London: Cambridge University Press.

Anagnostopoulos, Georgios, ed. 2009. Blackwell Companions to Philosophy: A Companion to Aristotle. London: Wiley-Blackwell. 
Barnes, Jonathan, ed. 1984. The Complete Works of Aristotle: The Revised Oxford Translation. Bollingen Series LXXI-2. Vol 1-2. Princeton (NJ): Princeton University Press.

Bays, Daniel. 2012. A New History of Christianity in China. London: Wiley-Blackwell.

Bradshaw, David. 2004. Aristotle East and West: Metaphysics and the Division of Christendom. Cambridge: Cambridge University Press.

Feng, Chengjun. 1931. A Textual Research on the Inscription of the Nestorianism Spreading in China (Jingjiao Bekao). Shanghai: Commercial Publishing House.

Lieu, Samuel N. C. 1980. "Nestorians and Manichaeans on the South China Coast." Vigiliae Christianae 34 (1), March: 71-88.

Marenbon, John, ed. 2004. Routledge History of Philosophy Volume III: Medieval Philosophy. London: Taylor \& Francis.

Mi, C. Michael. 1997. "The Spread of Aristotle's Theory in China." Political Theory 25 (2), Apr.: 249-57.

Saeki, P. Y. 1951. The Nestorian Documents and Relics in China. Tokyo: The Toho Bunkwa Gakuin/The Academy of Oriental Culture, Tokyo Institute.

Seung, Chul Kim. 1996. "Jesus the Bodhisattva: Jesus as Predicate.” Buddhist-Christian Studies 16: 192-93.

Taishō Shinshū Daizōkyō. 1934. 大正新修大藏经 (Taishō Tripitaka - New Revised Edition ), 1-100. Tōkyō: Daizō shuppan kabushiki-gaisha.

Vine, Aubrey. 1937. The Nestorian Churches: A Concise History of Nestorian Christianity in Asia from the Persian Schism to the Modern Assyrians. London: Independent Press.

Wang, Aihe. 2000. Cosmology and Political Culture in Early China. London: Cambridge University Press.

Wylie, A. 1856. “On the Nestorian Tablet of Se-gan Foo.” Journal of the American Oriental Society 5 (1855-1856): 275, 277-366. 